\title{
Phenylmethimazole blocks palmitate-mediated induction of inflammatory cytokine pathways in 3T3L1 adipocytes and RAW 264.7 macrophages
}

\author{
Kelly D McCall ${ }^{1,2,5}$, Dawn Holliday², Eric Dickerson ${ }^{2,3,6}$, Brian Wallace², Anthony L Schwartz ${ }^{2,5}$, \\ Christopher Schwartz ${ }^{2,3,6}$, Christopher J Lewis ${ }^{3}$, Leonard D Kohn ${ }^{2,3,4,6}$ and Frank L Schwartz ${ }^{1,2,5}$ \\ ${ }^{1}$ Department of Specialty Medicine, ${ }^{2}$ Appalachian Rural Health Institute, Diabetes Research Center, ${ }^{3}$ Edison Biotechnology Institute, ${ }^{4}$ Department of Biomedical \\ Sciences and ${ }^{5}$ Biomedical Engineering Program, Ohio University, Athens, Ohio 45701, USA \\ ${ }^{6}$ Interthyr Corporation, 534 4th Street, Woodinville, Washington 45750, USA \\ (Correspondence should be addressed to K D McCall who is now at 302B Academic Research Center, Ohio University, Athens, Ohio 45701, USA; \\ Email: mccallk@ohiou.edu)
}

\begin{abstract}
Visceral adipocytes and associated macrophages produce and release excessive amounts of biologically active inflammatory cytokines via the portal and systemic vascular system, which induce insulin resistance in insulin target tissues such as fat, liver, and muscle. Free fatty acids (FFAs) absorbed via the portal system or released from adipocytes also induce insulin resistance. In this report, we show that phenylmethimazole (C10) blocks basal IL6 and leptin production as well as basal Socs-3 expression in fully differentiated 3T3L1 cells (3T3L1 adipocytes) without affecting insulin-stimulated AKT signaling. In addition, C10 inhibits palmitate-induced IL6 and $i$ Nos up-regulation in both 3T3L1 adipocytes and RAW 264.7 macrophages, LPS-induced NF- $\mathrm{NB}$ and IFN- $\beta$ activation in 3T3L1 cells, and LPS-induced iNos, Ifn- $\beta$, Il1 $\beta, \operatorname{Cxcl10}$, and
\end{abstract}

Il6 expression in RAW 264.7 macrophages. C10 also blocks palmitate-induced Socs-3 up-regulation and insulin receptor substrate-1 (IRS-1) serine 307 phosphorylation in 3T3L1 adipocytes. Additionally, we show for the first time that although palmitate increases IRS-1 serine 307 phosphorylation in 3T3L1 adipocytes, AKT serine 473 phosphorylation is enhanced, not reduced, by palmitate. These results suggest that through inhibition of FFA-mediated signaling in adipocytes and associated macrophages, as well as possibly other insulin target cells/tissues (i.e. non-immune cells), C10 might be efficacious to prevent or reverse cytokine-induced insulin resistance seen in obesity-related insulin resistance and type 2 diabetes mellitus.

Journal of Endocrinology (2010) 207, 343-353

\section{Introduction}

The activation of inflammatory pathways in adipose and other tissues is an important mediator of obesity-related insulin resistance (Kahn \& Flier 2000, Lau et al. 2005). In obesity and type 2 diabetes mellitus (T2DM), visceral adipocytes and associated inflammatory cells (macrophages) produce and release excessive amounts of biologically active 'cytokines/adipokines' (TNF- $\alpha$, resistin, IL6, and PAI-1, etc.), which circulate via the portal and systemic vascular system to other insulin target tissues (liver, muscle and islet cells) and induce insulin resistance (Kahn \& Flier 2000, Steppan et al. 2001, Wellen \& Hotamisligil 2003, Lau et al. 2005). Excess saturated free fatty acids (FFAs) such as palmitate activate inflammation and induce insulin resistance via multiple mechanisms including, but not limited to, serine phosphorylation of insulin receptor substrate-1 (IRS-1) and up-regulation of suppressors of cytokine signaling (SOCS;
Paz et al. 1997, Lin et al. 2000, 2005, Emanuelli et al. 2001, Perreault \& Marette 2001, Aguirre et al. 2002, Chavez et al. 2003, Furukawa et al. 2004, Ajuwon \& Spurlock 2005, Boden et al. 2005, Hotamisligil 2005, Jove et al. 2005, Khamzina et al. 2005, Shi et al. 2006, Solinas et al. 2006, Nakamura et al. 2009, Ragheb et al. 2009). Therefore, agents capable of blocking FFA-mediated inflammation and insulin resistance may be useful as novel therapeutics for the treatment of T2DM.

We have previously shown that phenylmethimazole (C10) is effective in blocking toll-like receptor (TLR)-mediated activation of inflammatory pathways in non-immune cells (Dagia et al. 2004, Harii et al. 2005, McCall et al. 2007, Schwartz et al. 2009). Given that adipose tissue and associated macrophages are important sources of inflammatory molecules that mediate insulin resistance, we investigated the ability of C10 to block inflammatory pathways in 3T3L1 adipocytes and RAW 264.7 macrophages. 


\section{Materials and Methods}

\section{Control solvents}

Control solvents used were dimethyl sulfoxide (DMSO) and a proprietary FDA-approved cyclodextrin derivative. All experiments were conducted using C10 dissolved in both solvents for comparison of solvent effects. Both solvents produced similar results on all parameters measured.

\section{Materials}

3T3L1 cells were purchased from ATCC (Manassas, VA, USA). The IL6 ELISA kit was purchased from BioSource International (Camarillo, CA, USA). The Leptin ELISA kit was purchased from Alpha Diagnostics International (San Antonio, TX, USA). DMSO, LPS, and palmitate were obtained from Sigma-Aldrich. Phenylmethimazole (C10) and the proprietary FDA-approved cyclodextrin derivative were gifts of the Interthyr Corporation (Marietta, OH, USA).

\section{Phenylmethimazole (C10) solutions}

C10 was prepared as a fresh $200 \mathrm{mM}$ stock solution in $100 \%$ $(\mathrm{v} / \mathrm{v}) \mathrm{DMSO}$, and then diluted into medium at $37^{\circ} \mathrm{C}$ to achieve the noted concentrations in individual experiments. Since DMSO itself may have effects on different bioactivities, these studies also used $50 \mathrm{mM} \mathrm{C10} \mathrm{dissolved} \mathrm{in} 40 \%(\mathrm{v} / \mathrm{v})$ cyclodextrin by sonication at $50^{\circ} \mathrm{C}$ for $30 \mathrm{~min}$ and mixing on a rotary shaker at $37^{\circ} \mathrm{C}$ overnight. Again, C10 was diluted with medium to the noted concentrations in individual experiments. Regardless of the solvent used, C10 was similarly effective in all experiments, and its effects were not duplicated by either solvent.

\section{Cell culture}

Undifferentiated 3T3L1 cells were cultured in modified DMEM (ATCC 30-2002) containing $10 \%(\mathrm{v} / \mathrm{v})$ calf serum at $37^{\circ} \mathrm{C}$ in a $5 \% \mathrm{CO}_{2}$ incubator. RAW 264.7 cells were cultured in DMEM containing $10 \%(\mathrm{v} / \mathrm{v})$ fetal bovine serum (FBS) at $37^{\circ} \mathrm{C}$ in a $5 \% \mathrm{CO}_{2}$ incubator.

\section{Adipocyte differentiation}

Undifferentiated 3T3L1 cells were cultured as described above until confluency was reached. Two days post confluency, cells were placed in DMEM supplemented with $10 \%$ (v/v) FBS containing 0.5 mM 3-isobutyl-1-methylxanthine, $0.25 \mu \mathrm{M}$ dexamethasone, and $1 \mu \mathrm{g} / \mathrm{ml}$ insulin for induction of differentiation. Two days after induction of differentiation, the induction medium was replaced with DMEM supplemented with $10 \%$ (v/v) FBS containing $1 \mu \mathrm{g} / \mathrm{ml}$ insulin. The medium was then replaced again with fresh DMEM supplemented with $10 \%(\mathrm{v} / \mathrm{v})$ FBS every other day for the following 10-12 days.

\section{Palmitate treatments}

Palmitate solutions containing 2\% FFA-free BSA were prepared fresh in DMEM containing no serum immediately before each experiment. Cells were incubated for the indicated times with $0.75 \mathrm{mM}$ palmitate. A $2 \%$ BSA control was included with all palmitate treatments, and in all cases, no BSA effect was observed compared to untreated control.

\section{Luciferase assays}

The construction of the plasmid pIFN- $\beta$-Luciferase has been previously described (Harii et al. 2005). Briefly, to construct pIFN- $\beta$-Luciferase, the human IFN- $\beta$ promoter sequence was amplified from human genomic DNA (Clontech) using Ex Taq Polymerase (Takara, Madison, WI, USA). The PCR fragment contained the human IFN- $\beta$ promoter sequence from -125 to +34 relative to the transcription start site $(+1)$ and incorporated $\mathrm{KpnI}$ and XhoI restriction sites at the $5^{\prime}$ and $3^{\prime}$ ends respectively. The primers were as follows: hIFN- $\beta(-125) \mathrm{KpnI}\left(5^{\prime}\right.$-CAG GGT ACC GAG TTT TAG AAA CTA CTA AAA TG-3') and hIFN- $\beta(+34)$ XhoI (5'-GTA CTC GAG CAA AGG CTT CGA AAG G-3'). The fragment was digested with $\mathrm{KpnI}$ and XhoI, and then ligated into a similarly digested pGL3 Basic (Promega) vector. The plasmid $\mathrm{pNF}-\kappa \mathrm{B}-\mathrm{Luciferase}$ was purchased from Stratagene (La Jolla, CA, USA) (catalog \#219078). Undifferentiated 3T3L1 pre-adipocytes were grown to roughly $70 \%$ confluency, and were then transiently transfected with $100 \mathrm{ng}$ of luciferase reporter plasmid pNF- $\kappa B-L u c i f e r a s e$ or pIFN$\beta$-Luciferase and 2 ng of internal control plasmid phRL-TK using Lipofectamine 2000 according to the manufacturer's protocol (Invitrogen). Twenty four hours post transfection, cells were incubated with LPS $(1 \mu \mathrm{g} / \mathrm{ml})$, palmitate $(0.75 \mathrm{mM})$, and/or with palmitate plus $0.5 \mathrm{mM} \mathrm{C} 10$ or $0 \cdot 25 \%(\mathrm{v} / \mathrm{v})$ control solvent, and/or LPS plus $0.5 \mathrm{mM} \mathrm{C} 10$ or $0 \cdot 25 \%(\mathrm{v} / \mathrm{v})$ control solvent. Luciferase activity was measured using the Dual Luciferase Assay System from Promega.

\section{RT-PCR analysis}

3T3L1 adipocytes and RAW 264.7 cells were treated as indicated, and total RNA was isolated using the RNeasy Lipid Tissue Mini Kit from Qiagen according to the manufacturer's instructions. DNase was used to remove any contaminating DNA using the DNA-free kit from Ambion (Austin, TX, USA). cDNA was then synthesized using the RT-for-PCR kit from BD Biosciences (San Jose, CA, USA) according to the manufacturer's protocol. Mouse Socs-3 primers were as follows: sense primer, $5^{\prime}-\mathrm{CCC} \mathrm{TgC}$ ACA gCC CTC CTT TCT CAC-3'; antisense primer, $5^{\prime}-\mathrm{gCC}$ CCA CCC AgC CCC ATA CC- $3^{\prime}$. Mouse Gapdh primers were as follows: forward primer, $5^{\prime}$-ATg TCA gAT CCA CAA Cgg ATA CAT- $3^{\prime}$; reverse primer, $5^{\prime}$-ACT CCC TCA AgA TTg TCA gCA AT- $3^{\prime}$. The PCR conditions are as follows: $94{ }^{\circ} \mathrm{C}$ for $30 \mathrm{~s}, 30$ cycles of $94{ }^{\circ} \mathrm{C}$ for $1 \mathrm{~min}, 60{ }^{\circ} \mathrm{C}$ for 
$1 \mathrm{~min}, 72{ }^{\circ} \mathrm{C}$ for $1 \mathrm{~min}$, and $72{ }^{\circ} \mathrm{C}$ for $5 \mathrm{~min}$. Mouse $i$ Nos primers were as follows: $5^{\prime}$ primer, $5^{\prime}$-CCC TTC CgA AgT TTC Tgg CgA CAg Cgg C-3 ${ }^{\prime} ; 3^{\prime}$ primer, $5^{\prime}$-ggC TgT CAg AgC CTC gTg gCT TTg g- $3^{\prime}$. The PCR conditions are as follows: 35 cycles of $94{ }^{\circ} \mathrm{C}$ for $10 \mathrm{~s}, 58^{\circ} \mathrm{C}$ for $30 \mathrm{~s}, 72{ }^{\circ} \mathrm{C}$ for $10 \mathrm{~s}$, and $72^{\circ} \mathrm{C}$ for $5 \mathrm{~min}$. One nanogram of cDNA was used for PCR amplification of iNOS from RAW 264.7 macrophages. For all other PCRs, 50 ng cDNA was used.

\section{Western blot analyses}

3T3L1 adipocytes were treated as indicated, and cells were lysed using a lysis buffer which has been previously described (Carlson et al. 2004). For the detection of pIRS-1 (Ser ${ }^{307}$ ), $20 \mu \mathrm{g}$ of total protein was subjected to SDS-PAGE and western blot analysis to evaluate serine 307 phosphorylation of IRS-1 using an antibody specific for the detection of IRS-1 when phosphorylated at serine 307 from Cell Signaling Technology (Danvers, MA, USA). For the detection of phosphorylated AKT, $10 \mu \mathrm{g}$ of total protein was subjected to western blot analysis and identified using an anti-phosphoAKT serine 473 antibody from Cell Signaling Technology. Phospho-IRS-1 and phospho-AKT blots were stripped using a standard stripping buffer and re-probed using anti-IRS-1 or anti-AKT antibodies respectively from Cell Signaling Technology to detect protein levels independent of phosphorylation status. Blots were also stripped and re-probed with anti- $\beta$-actin antibody from Cell Signaling Technology as an internal loading control. The Magic Mark XP western Protein standard from Invitrogen was used for all western blots for protein molecular weight determination.

\section{Northern blot analyses}

RAW 264.7 cells were treated as indicated. RNA was extracted using Trizol (Invitrogen) and subjected to northern blot analysis in a manner similar to that described previously (Suzuki et al. 1999). The Gapdh cDNA was from Clontech. Other probe sequences were synthesized by RT-PCR (Suzuki et al. 1999) using the following cDNA specific primers: mouse Cxcl10, 5'-CCATCAGCACCATGAACCCAAGTCCTGCCG-3' and 5'-GGACGTCCTCCTCATCGTCGACTACACTGG-3' (469 bp); mouse $I l 1 \beta, 5^{\prime}$-CTCATCTGGGATCCTCTCCAGCCAAGCTTC- $3^{\prime}$ and $5^{\prime}$-CCATGGTTTCTTGTGACCCTGAGCGACCTG-3 (1006 bp); mouse Il6, 5'-CCAGTTGCCTTCTTGGGACTGATGCTGGTG- $3^{\prime}$ and $5^{\prime}$-GTCCTTAGCCACTCCTTCTGTGACTCCAGC-3' (530 bp); mouse If $n-\beta, 5^{\prime}$-AAGATCATTCTCACTGCAGCC-3' and 5'-TGAAGACTTCTGCTCGGACC-3' (586 bp).

\section{ELISAs}

Cell supernatants were collected following indicated treatments. For detection of basal IL6 levels in differentiated 3T3L1 cells, cell supernatant was collected and concentrated using YM3 centricon tubes from Millipore (Billerica, MA, USA). For all other ELISAs, cell supernatant removed directly from cells (NOT concentrated via YM3 centricon tubes) was used to determine IL6 levels via ELISA. The latter was not concentrated since inducible levels of IL6 are much higher than basal levels. For the Leptin ELISA, cell supernatants removed directly from cells were used to determine leptin levels. All ELISAs were performed according to the manufacturer's protocols.

\section{Statistical analyses}

All experiments were replicated at least three times on different groups of cells. All data are expressed as mean \pm s.D. Statistical significance was evaluated using one-way ANOVA, and statistical significance for comparison of means of different groups was calculated using Bonferroni's post hoc analyses.

\section{Results}

C10 decreases basal IL6, Socs-3, and leptin levels in 3T3L1 adipocytes, but does not affect basal IRS-1 serine 307

phosphorylation

Since adipocytes are known to produce adipokines that diminish insulin signaling, we evaluated the basal expression of IL6, Socs-3, and leptin in fully differentiated 3T3L1 cells and evaluated the effects of C10 on basal expression of these molecules. First, we measured the basal expression of IL6 protein in cell culture supernatants using ELISA, after the cell culture supernatants were concentrated 4-fold using YM3 centricon tubes from Millipore. 3T3L1 adipocytes express basal IL6 as evidenced by its presence in the supernatants (Fig. 1A, column 1), and C10 treatment significantly $(P<0 \cdot 001)$ reduced basal IL6 protein levels in the supernatants (Fig. 1A, column 3). Control solvent had no effect (Fig. 1A, column 2).

Since IL6 is a strong inducer of insulin resistance via its ability to up-regulate Socs-3 gene expression (Heinrich et al. 1998, 2003, Fasshauer \& Paschke 2003), we evaluated basal Socs-3 expression and the effects of C10 on basal Socs-3 expression in 3T3L1 adipocytes. Socs-3 was expressed basally in 3T3L1 adipocytes and C10 was effective at inhibiting its expression (Fig. 1B).

Of note, and suggesting this basal activity and the C10 effect were potentially relevant to disease expression, we measured the levels of leptin in the supernatants of 3T3L1 adipocytes (Table 1). We observed that measurable leptin levels were present in the supernatants of cultured 3T3L1 adipocytes and that $0.5 \mathrm{mM}$ C10 inhibited leptin production by these cells (Table 1). Although there was a solvent effect, C10 exhibited a much greater inhibitory effect than solvent alone, $P<0 \cdot 001$ (Table 1 ). 


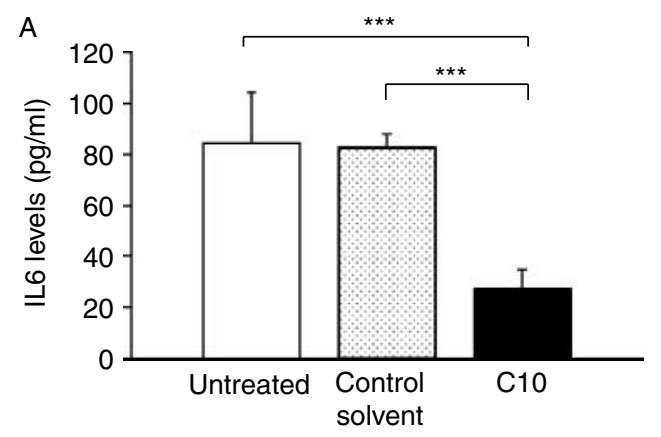

B

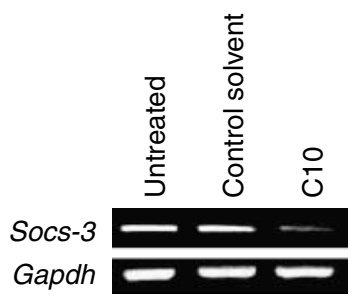

C

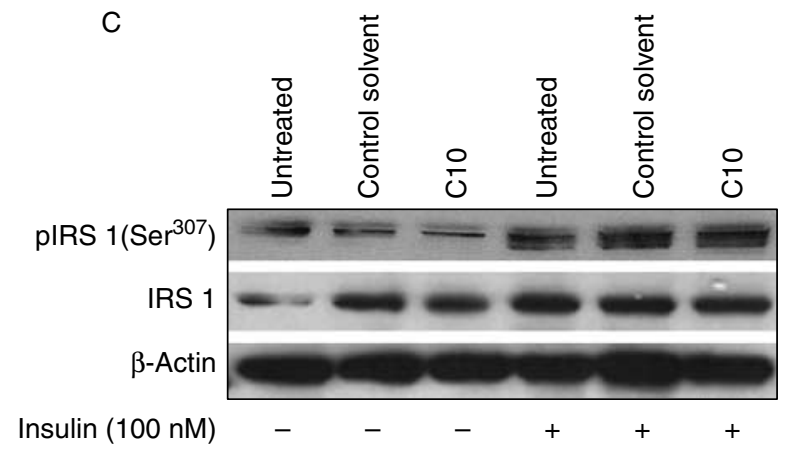

Figure 1 C10 decreases basal IL6, Socs-3, and leptin levels in 3T3L1 adipocytes, but does not affect basal IRS-1 serine 307 phosphorylation. 3T3L1 adipocytes were treated with $0.5 \mathrm{mM} \mathrm{C10}$ or $0.25 \%(\mathrm{v} / \mathrm{v})$ control solvent for $24 \mathrm{~h}$. (A) Cell culture supernatant was collected and concentrated using YM3 centricon tubes, and concentrated samples were then used to determine basal IL6 levels via ELISA analysis. Error bars represent S.D. Significance was determined using one-way ANOVA followed by Bonferroni's post hoc analysis. $* * * P<0 \cdot 001$ between groups as indicated. (B) Total RNA was isolated, and Socs-3 expression was measured by RT-PCR. Images shown are representative images from $\geq 3$ independent experiments. (C) 3T3L1 adipocytes were treated with palmitate $(0.75 \mathrm{mM})$ alone or in combination with $\mathrm{C} 10(0.5 \mathrm{mM})$ or control solvent $(0 \cdot 25 \%(\mathrm{v} / \mathrm{v}))$ for $24 \mathrm{~h}$ followed by stimulation with $100 \mathrm{nM}$ insulin for $10 \mathrm{~min}$ as indicated. Cell lysates were then prepared and subjected to SDS-PAGE and western blotting. IRS-1 serine 307 phosphorylation was detected using an anti-phospho-IRS-1 serine 307-specific antibody. Images shown are representative immunoblots from $\geq 3$ independent experiments.

It has been shown that serine and threonine phosphorylation of IRS-1, including serine residue 307 , by multiple kinases in response to FFAs, inflammatory cytokines, and insulin itself can impair insulin signaling in cells in culture (Zick 2005). Therefore, we evaluated the effects of C10 on basal levels of IRS-1 serine 307 phosphorylation in 3T3L1 adipocytes. Consistent with the other reports, we observed an increase in serine 307 phosphorylation of IRS-1 following insulin stimulation (Fig. 1C). C10 had no effect on either basal IRS-1 serine 307 phosphorylation or insulin-stimulated IRS-1 serine 307 phosphorylation (Fig. 1C).

\section{C10 does not block insulin-stimulated AKT signaling in 3T3L1 adipocytes}

For C10 to be a useful therapeutic agent, it is important that it blocks pathologic insulin resistance without affecting normal insulin signaling. Insulin stimulation leads to the activation of AKT via phosphorylation of multiple residues including serine residue 473 (Brozinick \& Birnbaum 1998). Thus, we evaluated the effects of C10 on insulin-stimulated AKT serine 473 phosphorylation in 3T3L1 adipocytes. As can be seen in Fig. 2, C10 did not block insulinstimulated AKT serine 473 phosphorylation in 3T3L1 adipocytes (Fig. 2).

\section{C10 inhibits palmitate-induced IL6 production, iNos} expression, and activation of $N F-\kappa B$ and IFN- $\beta$ signaling in 3T3L1 adipocytes

Excess saturated FFAs such as palmitate can reduce insulin sensitivity and glucose uptake. Some of the ways FFAs mediate insulin resistance are by up-regulating IL6 and iNos and by the activation of the NF- $\kappa \mathrm{B}$ and TLR 4 signaling pathways (Lin et al. 2000, Wellen \& Hotamisligil 2003, Ajuwon \& Spurlock 2005, Boden et al. 2005, Jove et al. 2005, Shi et al. 2006, Nakamura et al. 2009, Ragheb et al. 2009). First, 3T3L1 adipocytes were treated with palmitate with or without C10 or control solvent for $24 \mathrm{~h}$, and IL6 protein levels were measured. We observed a significant $(P<0 \cdot 01)$ increase in IL6 production following treatment with palmitate (Fig. 3A). Both C10 and control solvent exhibited an ability to significantly decrease palmitate-induced IL6 $(P<0 \cdot 01)$; however, it was clear in all experiments that $\mathrm{C} 10$ was much more potent at inhibiting palmitate-induced IL6 production than control solvent (Fig. 3A).

Next, we evaluated the effects of $\mathrm{C} 10$ on palmitateinduced $i$ Nos expression. 3T3L1 adipocytes were treated with palmitate plus or minus $\mathrm{C} 10$ for $24 \mathrm{~h}$, and $i$ Nos expression was

Table 1 C10 inhibits basal leptin levels in 3T3L1 adipocytes

Leptin levels $(\mathrm{pg} / \mathrm{ml})$

$\begin{array}{lc}\text { Untreated } & 2753 \pm 284 \cdot 0 \\ \text { Control solvent } & 1847 \pm 50 \cdot 7^{\mathrm{a}} \\ \text { C10 } & 498 \pm 40 \cdot 9^{\mathrm{a}, \mathrm{b}}\end{array}$

${ }^{\mathrm{a}}$ Indicates significant difference compared to untreated group.

BIndicates significant difference compared to control solvent group.

www.endocrinology-journals.org 


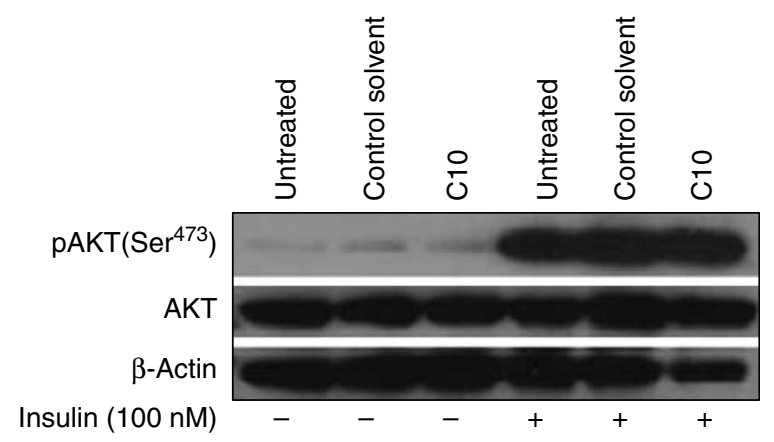

Figure 2 C10 does not block insulin-stimulated AKT signaling in 3T3L1 adipocytes. 3T3L1 adipocytes were treated with palmitate $(0.75 \mathrm{mM})$ alone or in combination with $\mathrm{C} 10(0.5 \mathrm{mM})$ or control solvent $(0 \cdot 25 \%(\mathrm{v} / \mathrm{v}))$ for $24 \mathrm{~h}$ followed by stimulation with $100 \mathrm{nM}$ insulin for $10 \mathrm{~min}$ as indicated. Total cell lysates were then prepared and directly subjected to SDS-PAGE and western blotting. AKT serine 473 phosphorylation was identified using an anti-phosphoAKT serine 473-specific antibody. Images shown are representative immunoblots from $\geq 3$ independent experiments.

evaluated via RT-PCR. Clearly, iNos was induced by palmitate, and C10 inhibited palmitate induction of $i$ Nos in these cells (Fig. 3B).

We also questioned whether $\mathrm{C} 10$ would inhibit increased $\mathrm{NF}-\kappa \mathrm{B}$ and IFN- $\beta$ signaling of palmitate in 3T3L1 cells. Undifferentiated 3T3L1 pre-adipocytes were transfected with

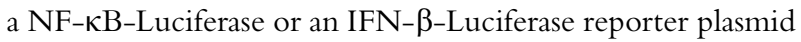
and treated with palmitate with or without $\mathrm{C} 10$, and relative luciferase activity was measured as an indicator of NF- $\kappa \mathrm{B}$ and IFN- $\beta$ promoter activity. Palmitate activated both NF- $\mathrm{KB}-$ Luciferase and IFN- $\beta$-Luciferase activity $(P<0 \cdot 01$ and $P<0.05$ respectively) (Fig. 3C), and C10 inhibited both palmitate-induced NF- $\mathrm{KB}$-Luciferase and IFN- $\beta$-Luciferase activity (Fig. 3C) $(P<0.01$ and $P<0.05$ respectively).

\section{C10 inhibits palmitate-induced IL6 production and iNos expression in RAW 264.7 macrophages}

Adipose-associated macrophages are also thought to play an important role in the pathogenesis of insulin resistance and T2DM (Weisberg et al. 2003, Xu et al. 2003, Curat et al. 2006). We questioned whether palmitate would increase IL6 and iNos in macrophages similar to that observed in 3T3L1 adipocytes, and whether such induction would be inhibited by C10.

Murine macrophage RAW 264.7 cells were incubated with palmitate in the absence or presence of C10, and IL6 protein levels were measured using an IL6-specific ELISA. Palmitate significantly increased IL6 protein levels, whereas C10 inhibited this induction (Fig. 4A). Additionally, we evaluated the effects of $\mathrm{C} 10$ on palmitate induction of iNos RNA expression via RT-PCR. Palmitate significantly increased iNos RNA levels, and this was inhibited by C10 (Fig. 4B).
C10 blocks palmitate-mediated up-regulation of Socs-3 expression in $3 T 3 L 1$ adipocytes

It is known that IL6 up-regulates Socs-3 expression to mediate insulin resistance (Heinrich et al. 1998, 2003, Fasshauer \& Paschke 2003); thus, we evaluated Socs-3 gene expression following treatment with palmitate and C10. As expected,

A

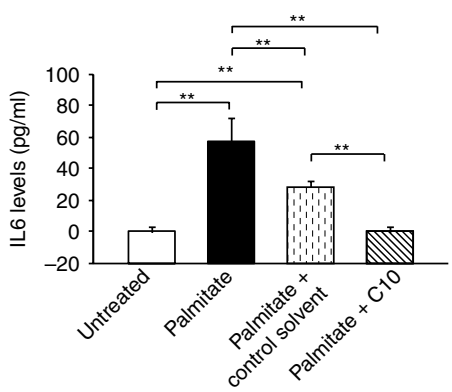

B
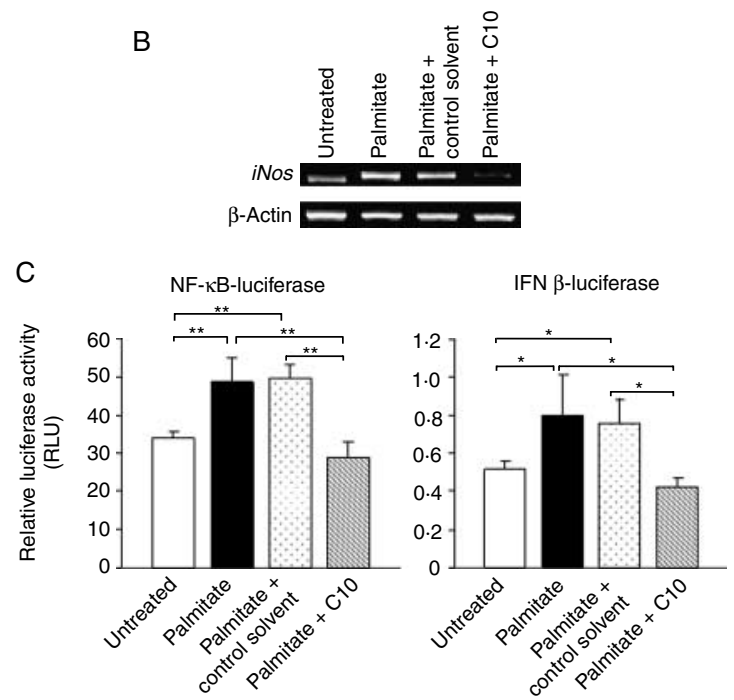

Figure $3 \mathrm{C} 10$ inhibits palmitate-induced IL6 production, iNos expression, and activation of NF- $\mathrm{KB}$ and IFN- $\beta$ signaling in $3 \mathrm{~T} 3 \mathrm{~L} 1$ cells. 3T3L 1 adipocytes were treated with palmitate $(0.75 \mathrm{mM})$ alone or in combination with $\mathrm{C} 10(0.5 \mathrm{mM})$ or control solvent $(0 \cdot 25 \%(\mathrm{v} / \mathrm{v}))$ for $24 \mathrm{~h}$. (A) Supernatant levels of IL6 were then measured using a mouse IL6-specific ELISA. Error bars represent s.D. Significance was determined using one-way ANOVA followed by Bonferroni's post hoc analysis. The brackets and ${ }^{* *}$ denote significance of $P<0 \cdot 01$ between groups as indicated. (B) Total RNA was isolated, cDNA was synthesized, and iNos and Gapdh were amplified by PCR as described in Materials and Methods. Images shown are representative images from $\geq 3$ independent experiments. (C) Undifferentiated 3T3L1 cells were transiently transfected with $100 \mathrm{ng}$ of luciferase reporter plasmid $\mathrm{pNF}-\kappa \mathrm{B}$-Luciferase or pIFN- $\beta$-Luciferase and 2 ng of internal control plasmid phRL-TK. Twenty four hours post transfection, cells were incubated with palmitate $(0.75 \mathrm{mM})$ alone or with $0 \cdot 25 \%(\mathrm{v} / \mathrm{v})$ control solvent or $0.5 \mathrm{mM} \mathrm{C} 10$ for $6 \mathrm{~h}$. Luciferase activity was measured using the Dual Luciferase Assay System (Promega). Error bars represent s.D. Significance was determined using one-way ANOVA followed by Bonferroni's post hoc analysis. ${ }^{* *} P<0 \cdot 01$ and ${ }^{*} P<0 \cdot 05$ between groups as indicated. 


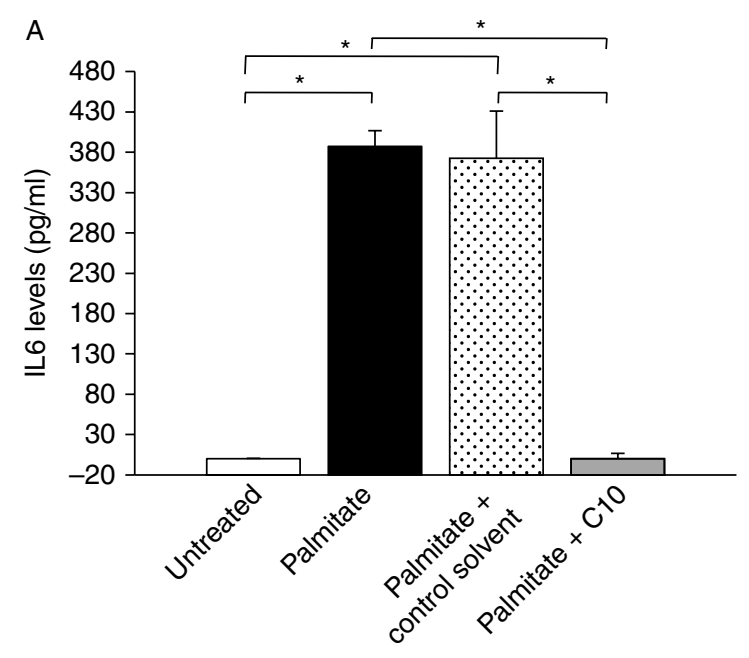

B

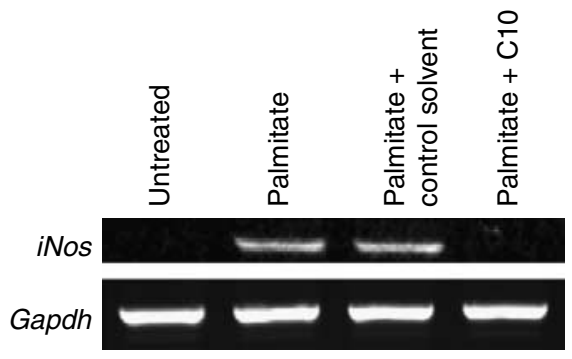

Figure 4 C10 inhibits palmitate-induced IL6 and iNos in RAW 264.7 macrophages. RAW 264.7 macrophages were treated with $0.75 \mathrm{mM}$ palmitate alone or in combination with $0.25 \%(\mathrm{v} / \mathrm{v})$ control solvent or $0.5 \mathrm{mM} \mathrm{C10}$ for $24 \mathrm{~h}$. (A) Supernatant levels of IL6 were then measured using a mouse IL6-specific ELISA.

Significance was determined using one-way ANOVA followed by Bonferroni's post hoc analysis. ${ }^{*} P<0 \cdot 0000001$ between groups as indicated. (B) Total RNA was isolated, and RT-PCR was then performed to evaluate $i$ Nos expression. Fifty nanograms of cDNA were used as a template for PCR. Images shown are representative images from $\geq 3$ independent experiments.

Socs-3 gene expression increased following palmitate treatment in 3T3L1 adipocytes, and this induction was inhibited by C10 (Fig. 5). In this case, control solvent had no effect on palmitate induction of Socs-3 gene expression (Fig. 5).

C10 blocks LPS-induced NF- $K B$ and IFN- $\beta$ activation in $3 T 3 L 1$ cells, and LPS-induced iNos, Ifn- $\beta$, Il1 $\beta, \operatorname{Cxcl10,}$ and $\mathrm{Il} 6$ gene expression, as well as IL6 protein production in $R A W 264.7$ macrophages

Since C10 has been shown to block TLR signaling in other cell types (Dagia et al. 2004, Harii et al. 2005, McCall et al. 2007, Schwartz et al. 2009), we questioned whether C10 may be blocking TLR signaling in 3T3L1 cells and RAW 264.7 macrophages. TLR 4 signaling has been implicated in the development of insulin resistance (Lin et al. 2000, Shi et al. 2006); thus, we questioned whether C10 could inhibit LPSinduced inflammatory signaling in these cell lines. We first confirmed that TLR 4 is present in both undifferentiated and fully differentiated 3T3L1 cells as well as in RAW 264.7 macrophages (data not shown).

We then questioned whether C10 would inhibit LPSinduced NF- $\kappa \mathrm{B}$ and IFN- $\beta$ signaling in 3T3L1 cells. Undifferentiated 3T3L1 cells were transfected with a NF- $\kappa \mathrm{B}-$ Luciferase or an IFN- $\beta$-Luciferase reporter plasmid. Transfected cells were then treated with LPS with or without $\mathrm{C} 10$, and then measured for relative luciferase activity as a measure of $\mathrm{NF}-\kappa \mathrm{B}$ and IFN- $\beta$ promoter activity. LPS significantly induced the activation of NF- $\kappa \mathrm{B}-$ Luciferase and IFN- $\beta$-Luciferase activity $(P<0.01$ and $P<0.05$ respectively), and $\mathrm{C} 10$ inhibited both LPS-induced NF- $\kappa$ B-Luciferase and IFN- $\beta$-Luciferase activity $(P<0 \cdot 01$ and $P<0.05$ respectively) (Fig. 6A).

Next, we questioned whether $\mathrm{C} 10$ had similar effects on LPS induction of other inflammatory molecules in RAW 264.7 macrophages. First, we evaluated the effects of C10 on LPS-induced iNos gene expression using RT-PCR. C10 largely reduced LPS induction of $i$ Nos (Fig. 6B). Next, we evaluated the effects of C10 on LPS induction of IL6 using ELISA. LPS greatly induced the production of IL6, and C10 significantly blocked this induction (Fig. 6C). Finally, to confirm these results, RAW 264.7 cells were treated with LPS, and northern blot analyses were conducted to evaluate the expression of $I f n-\beta, I l 1 \beta, C x c l 10$, and $I l 6$ over a $6 \mathrm{~h}$ time course. After $1 \mathrm{~h}$ of LPS treatment, If $n-\beta, I l 1 \beta$, and Cxcl10 were largely up-regulated (Fig. 6D). Il6 up-regulation by LPS was evident after $3 \mathrm{~h}$ (Fig. 6D). C10 inhibited LPS induction of all of the genes evaluated (Ifn- $\beta$, Il1 $\beta$, Cxcl10, and Il6) (Fig. 6D).

\section{C10 blocks palmitate-induced IRS-1 serine 307 phosphorylation in $3 T 3 L 1$ adipocytes}

Since elevated FFAs have been shown to impair insulin action via serine phosphorylation of IRS-1 (Paz et al. 1997, Aguirre et al. 2002, Hotamisligil 2005), we evaluated the effects of

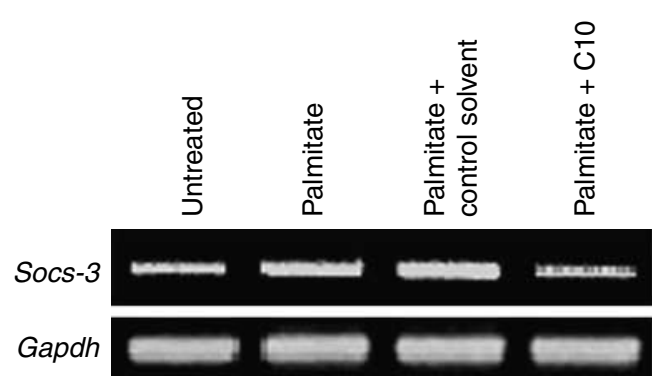

Figure 5 C10 inhibits palmitate-induced Socs-3 expression in 3T3L1 adipocytes. 3T3L1 adipocytes were treated with palmitate $(0.75 \mathrm{mM})$ alone or in combination with $\mathrm{C} 10(0.5 \mathrm{mM})$ or control solvent $(0 \cdot 25 \%(\mathrm{v} / \mathrm{v}))$ for $24 \mathrm{~h}$. Total RNA was isolated, cDNA was synthesized, and Socs-3 and Gapdh were amplified by RT-PCR as described in Materials and Methods. Images shown are representative images from $\geq 3$ independent experiments. 
palmitate on induction of IRS-1 serine 307 phosphorylation in 3T3L1 adipocytes. In non-insulin-stimulated 3T3L1 adipocytes, we observed increases in IRS-1 serine 307 phosphorylation within $6 \mathrm{~h}$ of palmitate treatment, but by 16 h, IRS-1 serine 307 phosphorylation was diminished back to basal levels (Fig. 7A). Additionally, we observed increases in IRS-1 serine 307 phosphorylation with insulin treatment and a further enhancement of insulin-stimulated IRS-1 serine 307 phosphorylation with palmitate treatment up to $16 \mathrm{~h}$ (Fig. 7A); by 24 h, however, insulin-stimulated IRS-1 serine
307 phosphorylation was back to basal levels (data not shown). C10 blocked palmitate induction of IRS-1 serine 307 phosphorylation in 3T3L1 adipocytes (Fig. 7B)

\section{Palmitate enhances insulin-stimulated AKT serine 473 phosphorylation in 3T3L1 adipocytes}

Given that palmitate increased IRS-1 serine 307 phosphorylation, we questioned whether palmitate had any influence on insulin signaling in 3T3L1 adipocytes. Insulin stimulation leads
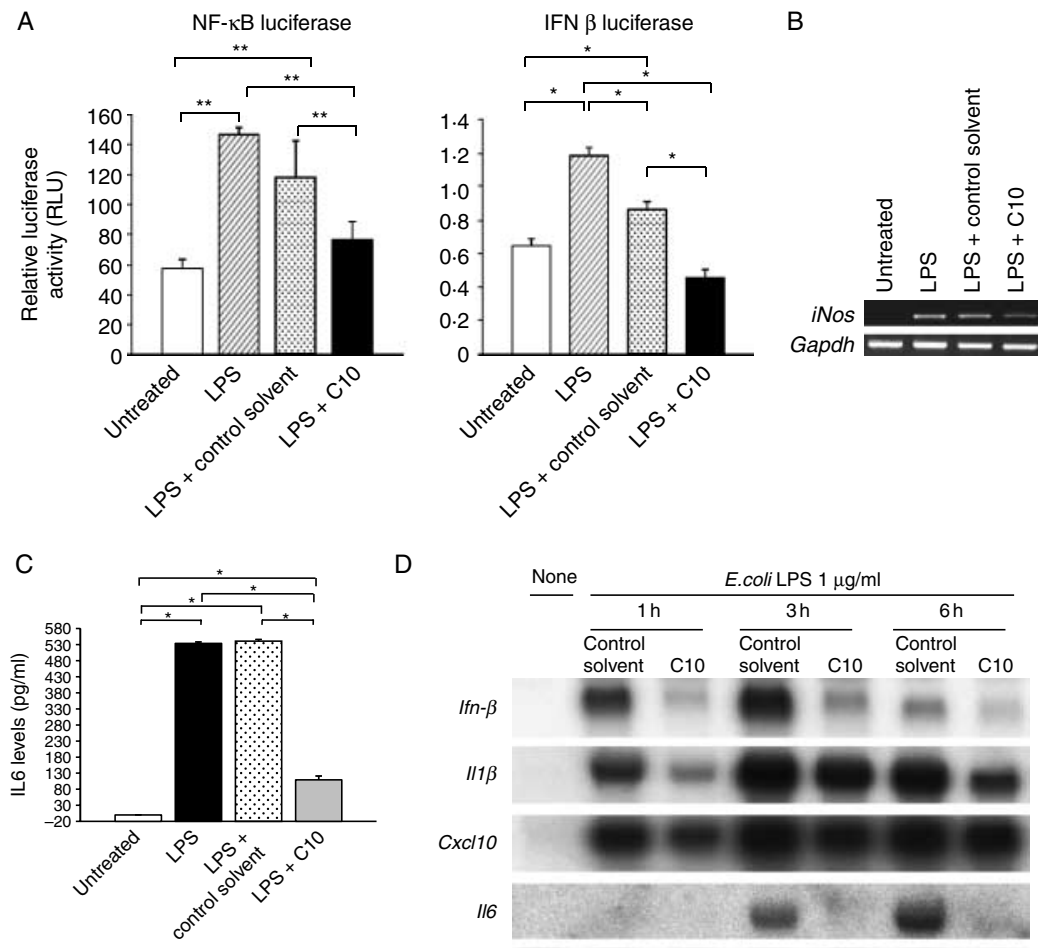

D

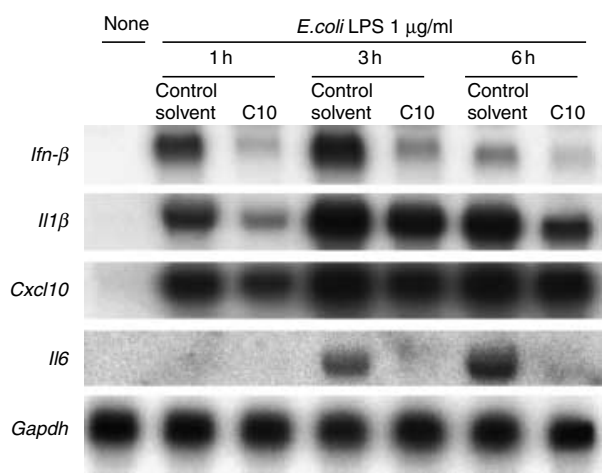

Figure 6 C10 blocks LPS-induced signaling in 3T3L1 cells and RAW 264.7 macrophages. (A) Undifferentiated 3T3L1 cells were transiently transfected with $100 \mathrm{ng}$ of luciferase reporter plasmid pNF- $\kappa B$-Luciferase or pIFN- $\beta$-Luciferase and 2 ng of internal control plasmid phRL-TK. Twenty four hours post transfection, cells were incubated with LPS $(1 \mu \mathrm{g} / \mathrm{ml})$ alone or with $0.5 \mathrm{mM} \mathrm{C10}$ or $0 \cdot 25 \%(\mathrm{v} / \mathrm{v})$ control solvent for $6 \mathrm{~h}$. Luciferase activity was measured using the Dual Luciferase Assay System (Promega). Error bars represent S.D. Significance was determined using one-way ANOVA followed by Bonferroni's post hoc analysis. ${ }^{*} P<0.01$ and ${ }^{*} P<0.05$ between groups as indicated. (B and C) RAW 264.7 macrophages were treated with $50 \mathrm{ng} / \mathrm{ml}$ LPS alone or in combination with $0.25 \%(\mathrm{v} / \mathrm{v})$ control solvent or $0.5 \mathrm{mM} \mathrm{C10} \mathrm{for} 4 \mathrm{~h}$. (B) RT-PCR was then performed to evaluate iNos expression. One nanogram of cDNA was used as a template for PCR. Images shown are representative images from $\geq 3$ independent experiments. (C) Supernatant levels of IL6 were then measured using a mouse IL6-specific ELISA. Significance was determined using one-way ANOVA followed by Bonferroni's post hoc analysis. ${ }^{*} P<0 \cdot 0000001$ between groups as indicated. (D) RAW 264.7 cells were treated with $1 \mu \mathrm{g} / \mathrm{ml}$ LPS alone or in combination with $0.25 \%(\mathrm{v} / \mathrm{v})$ control solvent or $0.5 \mathrm{mM} \mathrm{C} 10$ for 1,3 , and $6 \mathrm{~h}$. Total RNA was then collected, and northern blot analysis was conducted to evaluate the expression of Ifn- $\beta$, $I / 1 \beta$, Cxcl10, and II6. Gapdh served as a loading control. Images shown are representative images from $\geq 3$ independent experiments. 
A

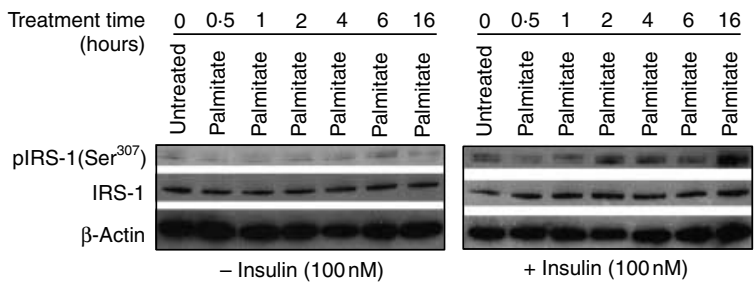

B

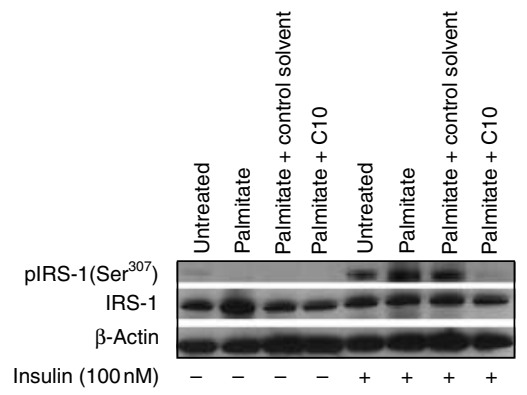

Figure 7 C10 blocks palmitate-induced IRS-1 serine 307 phosphorylation in 3T3 1 adipocytes. (A) 3T3 1 1 adipocytes were treated with palmitate $(0.75 \mathrm{mM})$ for the designated times followed by stimulation with $100 \mathrm{nM}$ insulin for $10 \mathrm{~min}$ as indicated. Cell lysates were prepared and subjected to SDS-PAGE and western blotting. IRS-1 serine 307 phosphorylation was detected using an anti-phospho-IRS-1 serine 307-specific antibody. (B) 3T3L1 adipocytes were treated with palmitate $(0.75 \mathrm{mM})$ alone or in combination with C10 $(0.5 \mathrm{mM})$ or control solvent $(0 \cdot 25 \%(\mathrm{v} / \mathrm{v}))$ for $16 \mathrm{~h}$ followed by stimulation with $100 \mathrm{nM}$ insulin for $10 \mathrm{~min}$ as indicated. Total cell lysates were then prepared and directly subjected to SDS-PAGE and western blotting. IRS-1 serine 307 phosphorylation was detected using an anti-phospho-IRS-1 serine 307-specific antibody. Images shown are representative immunoblots from $\geq 3$ independent experiments.

to the activation of AKT via phosphorylation of multiple residues including serine residue 473 (Brozinick \& Birnbaum 1998). Thus, we questioned whether palmitate could block insulin-stimulated AKT phosphorylation in 3T3L1 adipocytes. Surprisingly, palmitate enhanced insulin-stimulated AKT phosphorylation in these cells (Fig. 8A). C10 had no effect on palmitate-induced AKT phosphorylation (Fig. 8B).

\section{Discussion}

There is a general consensus that visceral obesity plays a significant role in the pathogenesis of T2DM through induction of insulin resistance (Lau et al. 2005). The insulin resistance induced by obesity is in part secondary to the release of circulating pro-inflammatory cytokines/adipokines from adipocytes and macrophages, which, through their downstream effectors in other target tissues such as liver, muscle, etc. induce insulin resistance. Ectopic fat deposition from excessive circulating levels of FFA's within somatic cells and their consequent release of these same proinflammatory adipokines/cytokines within insulin target cells can also induce insulin resistance (Smith \& Ravussin 2002,
Wellen \& Hotamisligil 2003) commonly termed 'lipotoxicity'. The mechanisms by which excess FFAs contribute to insulin resistance are not well understood; however, recent studies show that FFAs can induce insulin resistance by activating the $\mathrm{NF}-\kappa \mathrm{B}$, protein kinase $\mathrm{C}$, c-Jun $\mathrm{NH}_{2}$-terminal kinase, and TLR signaling pathways (Lin et al. 2000, Ajuwon \& Spurlock 2005, Boden et al. 2005, Jove et al. 2005, Shi et al. 2006, Solinas et al. 2006, Nakamura et al. 2009, Ragheb et al. 2009).

Here, we confirm that the saturated FFA palmitate is a strong inducer of the inflammatory cytokine pathways known to mediate insulin resistance in 3T3L1 adipocytes, and that palmitate is also a strong inducer of inflammatory pathways that produce cytokines/molecules that mediate insulin resistance in RAW 264.7 macrophages as well. Specifically, we show that palmitate can induce significant increases in IL6 and $i$ Nos production in both cell types. In 3T3L1 adipocytes, palmitate-induced IL6 production resulted in Socs-3 up-regulation, providing additional evidence to suggest that FFAs are important in the development of insulin resistance since SOCS-3 inhibits tyrosine phosphorylation of IRS-1 and IRS-2 (Ueki et al. 2004). The observed palmitate-induced up-regulation of $i$ Nos lends even more support to the

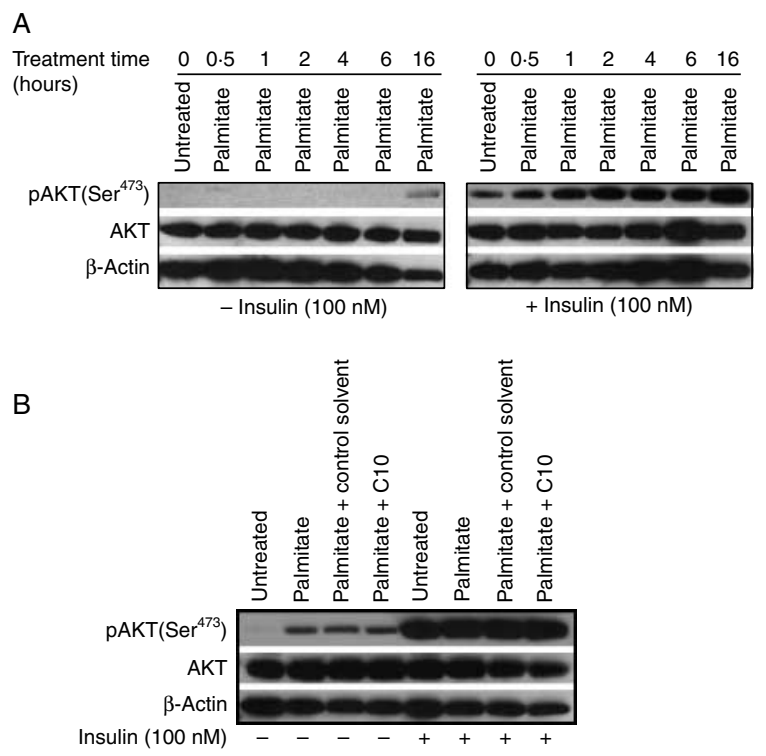

Figure 8 Palmitate enhances insulin-stimulated AKT serine 473 phosphorylation in 3T3L1 adipocytes. (A) 3T3L1 adipocytes were treated with palmitate $(0.75 \mathrm{mM})$ for the designated times followed by stimulation with $100 \mathrm{nM}$ insulin for $10 \mathrm{~min}$ as indicated. Cell lysates were then prepared and subjected to SDS-PAGE and western blotting. AKT serine 473 phosphorylation was identified using an anti-phospho-AKT serine 473-specific antibody. (B) 3T3L1 adipocytes were treated with palmitate $(0.75 \mathrm{mM})$ alone or in combination with C10 $(0.5 \mathrm{mM})$ or control solvent $(0 \cdot 25 \%(\mathrm{v} / \mathrm{v}))$ for $16 \mathrm{~h}$ followed by stimulation with $100 \mathrm{nM}$ insulin for $10 \mathrm{~min}$ as indicated. Total cell lysates were then prepared and directly subjected to SDS-PAGE and western blotting. IRS-1 serine 307 phosphorylation was detected using an anti-phospho-IRS-1 serine 307-specific antibody. Images shown are representative immunoblots from $\geq 3$ independent experiments. 
importance of FFAs in the development of insulin resistance since up-regulation of $i$ Nos has been shown to contribute to inflammation-induced insulin resistance (Perreault \& Marette 2001). Most importantly, we report the novel finding that C10 is effective at blocking palmitate and LPS-induced activation of IL6 and $i$ Nos-producing inflammatory pathways in both 3T3L1 adipocytes and RAW 264.7 macrophages without blocking insulin-stimulated AKT signaling, suggesting that C10 may be efficacious as a novel therapeutic agent for the treatment of obesity/inflammation-induced insulin resistance. Furthermore, since C10 inhibits LPS and palmitate induction of $i$ Nos expression in both adipocytes and macrophages, it might also be beneficial in correcting the stress-induced hyperglycemia observed in acute inflammatory processes such as infection/sepsis (Berstein 2005, De Souza et al. 2005, Elsammak et al. 2005). It is clear, however, that additional studies into the effects of C10 on FFA-induced insulin resistance (i.e. glucose uptake assays, etc.) in adipocytes and other insulin target tissues such as skeletal muscle and liver are warranted before clinical efficacy can be established.

Since palmitate is the major FFA released from 3T3L1 adipocytes, and palmitate induces the expression of inflammatory molecules in 3T3L1 adipocytes, it is not surprising that we observed basal expression of inflammatory pathway products such as IL6, Socs-3, and $i$ Nos as well as basal levels of IRS-1 serine 307 in 3T3L1 adipocytes. The fact that C10 effectively reduced basal levels of IL6, Socs-3, and leptin in addition to palmitateinduced IL6, Socs-3, and iNos levels in 3T3L1 adipocytes lends support to the notion that C10 specifically blocks palmitatemediated inflammatory pathways.

Although insignificant compared to the effects of C10, in some assays, we observed a significant effect of control solvent on palmitate-induced IL6 production and palmitate-induced IFN- $\beta$-Luciferase activity in 3T3L1 cells. This was seen with two different solvents used herein, DMSO and cyclodextrin. It is not clear at this time why both solvents, which are unrelated chemically, give similar results, nor is the mechanism of this phenomenon understood. Despite the finding that control solvent significantly inhibited palmitateinduced IL6 production, we observed no effect of control solvent on palmitate induction of Socs-3 gene expression in 3T3L1 adipocytes. At this time, we can only speculate that the control solvent might be modulating a different signaling pathway from that effecting Socs-3 expression.

Given that C10 effectively reduced basal levels of IL6, Socs-3, and leptin in addition to palmitate-induced IL6, Socs-3, iNos, and IRS-1 serine 307 levels in 3T3L1 adipocytes, we observed no effect of C10 on basal IRS-1 serine 307 levels via western blot analysis. Perhaps the levels of palmitate secreted from 3T3L1 adipocytes in culture are insufficient to elicit a measurable change in IRS-1 serine 307 phosphorylation with C10 treatment that is detectable by conventional western blotting. We encountered a similar situation when measuring basal levels of IL6 as well; concentration of cell culture media was necessary prior to ELISA measurement, as basal IL6 levels in cell culture media were too low to detect without centricon concentration of media prior to ELISA as described in Materials and Methods.

Recently, the 'abnormal' expression of TLR in nonimmune cells and their resultant overexpression of the same immunomodulatory molecules such as IL6 and TNF- $\alpha$ which are known to be important in the onset/progression of T2DM, have been recognized (Lin et al. 2000). TLR4 has been reported in 3T3L1 adipocytes (Lin et al. 2000), and LPS as well as FFA treatment results in the activation of TLR 4 and consequent IL6 and TNF- $\alpha$ production, which is not observed in Tlr 4 knockdown adipocytes (Lin et al. 2000); directly linking Tlr4 expression in adipocytes and insulin resistance. We have previously shown that $\mathrm{C} 10$ can block TLR3-mediated expression and signaling in multiple tissues (Harii et al. 2005, McCall et al. 2007, Schwartz et al. 2009). In this study, we also demonstrate that C10 can block LPS and palmitate-mediated NF- $\mathrm{BB}$ and IFN- $\beta$ activation as well as LPS-induced $i$ Nos, Ifn- $\beta, I l 1 \beta$, Cxcl10, and $I l 6$ gene expression, and IL6 protein production. Since these are all downstream products of both TLR 3 and TLR 4 signaling, it suggests that C10 may prevent palmitate-mediated up-regulation of IL6 and iNos in 3T3L1 adipocytes and RAW 264.7 macrophages, at least in part, by blocking palmitate-mediated TLR signaling. Although these data are suggestive of TLR specificity, additional studies need to be conducted to identify if this activity of C10 is specific to palmitate activation of TLR4 signaling or if C10 may be affecting other pathways that up-regulate IL6 and $i$ Nos.

Multiple studies have suggested that elevated FFAs impair insulin action via serine 307 phosphorylation of IRS-1 (Hotamisligil et al. 1996, Paz et al. 1997, Aguirre et al. 2000, 2002, Hirosumi et al. 2002, Yu et al. 2002, Um et al. 2004, Morino et al. 2005, Zick 2005, Ragheb et al. 2009). Thus, in an attempt to evaluate the efficacy of C10 to block palmitate-induced insulin resistance and restore insulin sensitivity, we looked at the effects of $\mathrm{C} 10$ on palmitate-induced up-regulation of IRS-1 serine 307 phosphorylation in 3T3L1 adipocytes. We found that C10 effectively blocked palmitateinduced serine 307 phosphorylation of IRS-1, suggesting that C10 may be effective in restoring insulin sensitivity in adipocytes.

Insulin increases glucose transport in muscle and adipose tissue by stimulating the translocation of GLUT- 4 to the cell surface, a process that requires the activation of AKT (Kohn et al. 1996). This event predominately relies on insulinstimulated threonine 308 and serine 473 phosphorylation of AKT (Vanhaesebroeck \& Alessi 2000). FFA-induced IRS-1 serine 307 phosphorylation is postulated to induce insulin resistance by blocking interactions with the insulin receptor, which blocks the downstream phosphorylation of AKT (Paz et al. 1997, Aguirre et al. 2002). Since no correlation between palmitate-induced up-regulation of IRS-1 serine 307 phosphorylation and consequent down-regulation of AKT serine 473 phosphorylation in 3T3L1 adipocytes has been reported, we evaluated the effects of palmitate on AKT serine 473 phosphorylation in 3T3L1 adipocytes in culture. Instead of observing an expected decrease in AKT serine 473 
phosphorylation with palmitate treatment, we surprisingly observed that insulin-stimulated phosphorylation of AKT serine 473 increased linearly over time with palmitate treatment; a novel finding. This finding is, however, consistent with a 2008 report by Banerjee et al. (2008), showing that in human hepatocytes infected with chronic hepatitis $\mathrm{C}$ virus (HCV) core protein, phosphorylation of IRS-1 serine 312 (the human equivalent of murine serine 307 ) is increased which correlated with an increase in AKT serine 473 phosphorylation, while IRS-1 threonine 308 phosphorylation was not significantly altered. This same study showed that overexpression of the HCV core protein alone or $\mathrm{HCV}$ infection induced insulin resistance as measured by HCV-mediated suppression of 2-deoxy-D- $\left[{ }^{3} \mathrm{H}\right]$ glucose uptake (Banerjee et al. 2008). Taken together, these results suggest that perhaps palmitate-induced IRS-1 serine 307 phosphorylation mediates insulin resistance via a pathway that is independent of AKT serine 473 phosphorylation status. In the absence of additional studies, the significance of palmitate-mediated increases in AKT serine 473 phosphorylation and its relationship to insulin resistance remain unclear.

Since palmitate increased insulin-stimulated AKT serine 473 phosphorylation in 3T3L1 adipocytes, and since C10 blocked palmitate-induced increases in IRS- 1 serine 307 phosphorylation, we were curious to see what effects, if any, C10 might have on palmitate-induced AKT serine 473 phosphorylation. We observed no inhibitory effect of C10 on palmitatemediated increases in AKT serine 473 phosphorylation with $16 \mathrm{~h}$ of palmitate treatment. Additional studies of the effects of C10 on palmitate-induced AKT serine 473 phosphorylation over time are clearly needed before conclusions can be made; however, these studies may help to elucidate additional information about C10 mechanism of action.

Together these observations suggest that through inhibition of FFA-mediated signaling in adipocytes and possibly other insulin target cells/tissues (i.e. non-immune cells) or associated macrophages, C10 might be efficacious to prevent or reverse cytokine-induced insulin resistance seen in obesityrelated insulin resistance and T2DM. Studies are currently underway to evaluate the efficacy of C10 to restore insulin sensitivity in palmitate-treated adipocytes, hepatocytes, and myocytes, as well as in animal models of obesity-related insulin resistance and T2DM.

\section{Declaration of interest}

K D M, A L S, L D K, and F L S are co-inventors on a continuation-in-part of US Pat. App. Ser. No. 11/130922 (2008). K D M and A L S have previously consulted for the Interthyr Corporation. L D K has equity interests in the Interthyr Corporation. K D M, A L S, L D K, and F L S are participants of a funded NIH grant application. E D and C S were previously employed by the Interthyr Corporation. $\mathrm{D} \mathrm{H}, \mathrm{C} \mathrm{J} \mathrm{L}$, and $\mathrm{B} \mathrm{W}$ have nothing to disclose.

\section{Funding}

This work was supported, in part, by the Interthyr Corporation and Ohio University.

\section{References}

Aguirre V, Uchida T, Yenush L, Davis R \& White MF 2000 The c-Jun $\mathrm{NH}(2)$-terminal kinase promotes insulin resistance during association with insulin receptor substrate-1 and phosphorylation of Ser(307). Journal of Biological Chemistry 275 9047-9054. (doi:10.1074/jbc.275.12.9047)

Aguirre V, Werner ED, Giraud J, Lee YH, Shoelson SE \& White MF 2002 Phosphorylation of Ser307 in insulin receptor substrate-1 blocks interactions with the insulin receptor and inhibits insulin action. Journal of Biological Chemistry 277 1531-1537. (doi:10.1074/jbc.M101521200)

Ajuwon KM \& Spurlock ME 2005 Palmitate activates the NF-kappaB transcription factor and induces IL-6 and TNFalpha expression in 3T3-L1 adipocytes. Journal of Nutrition 135 1841-1846.

Banerjee S, Saito K, Ait-Goughoulte M, Meyer K, Ray RB \& Ray R 2008 Hepatitis $\mathrm{C}$ virus core protein upregulates serine phosphorylation of insulin receptor substrate- 1 and impairs the downstream akt/protein kinase B signaling pathway for insulin resistance. Journal of Virology 82 2606-2612. (doi:10.1128/JVI.01672-07)

Berstein LM 2005 Clinical usage of hypolipidemic and antidiabetic drugs in the prevention and treatment of cancer. Cancer Letters 224 203-212. (doi:10.1016/j.canlet.2004.11.011)

Boden G, She P, Mozzoli M, Cheung P, Gumireddy K, Reddy P, Xiang X, Luo Z \& Ruderman N 2005 Free fatty acids produce insulin resistance and activate the proinflammatory nuclear factor-kappaB pathway in rat liver. Diabetes 54 3458-3465. (doi:10.2337/diabetes.54.12.3458)

Brozinick JT Jr \& Birnbaum MJ 1998 Insulin, but not contraction, activates Akt/PKB in isolated rat skeletal muscle. Journal of Biological Chemistry 273 14679-14682. (doi:10.1074/jbc.273.24.14679)

Carlson CJ, White MF \& Rondinone CM 2004 Mammalian target of rapamycin regulates IRS-1 serine 307 phosphorylation. Biochemical and Biophysical Research Communications 316 533-539. (doi:10.1016/j.bbrc.2004.02.082)

Chavez JA, Knotts TA, Wang LP, Li G, Dobrowsky RT, Florant GL \& Summers SA 2003 A role for ceramide, but not diacylglycerol, in the antagonism of insulin signal transduction by saturated fatty acids. Journal of Biological Chemistry 278 10297-10303. (doi:10.1074/jbc.M212307200)

Curat CA, Wegner V, Sengenes C, Miranville A, Tonus C, Busse R \& Bouloumie A 2006 Macrophages in human visceral adipose tissue: increased accumulation in obesity and a source of resistin and visfatin. Diabetologia 49 744-747. (doi:10.1007/s00125-006-0173-z)

Dagia NM, Harii N, Meli AE, Sun X, Lewis CJ, Kohn LD \& Goetz DJ 2004 Phenyl methimazole inhibits TNF-alpha-induced VCAM-1 expression in an IFN regulatory factor-1-dependent manner and reduces monocytic cell adhesion to endothelial cells. Journal of Immunology 173 2041-2049.

De Souza CT, Araujo EP, Bordin S, Ashimine R, Zollner RL, Boschero AC, Saad MJ \& Velloso LA 2005 Consumption of a fat-rich diet activates a proinflammatory response and induces insulin resistance in the hypothalamus. Endocrinology 146 4192-4199. (doi:10.1210/en.2004-1520)

Elsammak M, Refai W, Elsawaf A, Abdel-Fattah I, Abd Elatti E \& Ghazal A 2005 Elevated serum tumor necrosis factor alpha and ferritin may contribute to the insulin resistance found in HCV positive Egyptian patients. Current Medical Research and Opinion 21 527-534. (doi:10.1185/030079905X38141)

Emanuelli B, Peraldi P, Filloux C, Chavey C, Freidinger K, Hilton DJ, Hotamisligil GS \& Van Obberghen E 2001 SOCS-3 inhibits insulin signaling and is up-regulated in response to tumor necrosis factor-alpha in the adipose tissue of obese mice. Journal of Biological Chemistry 276 47944-47949. (doi:10.1074/jbc.M104602200)

Fasshauer M \& Paschke R 2003 Regulation of adipocytokines and insulin resistance. Diabetologia 46 1594-1603. (doi:10.1007/s00125-003-1228-z)

Furukawa S, Fujita T, Shimabukuro M, Iwaki M, Yamada Y, Nakajima Y, Nakayama O, Makishima M, Matsuda M \& Shimomura I 2004 Increased oxidative stress in obesity and its impact on metabolic syndrome. Journal of Clinical Investigation 114 1752-1761. (doi:10.1172/JCI21625)

Harii N, Lewis C, Vasko V, McCall K, Benavides-Peralta U, Sun X, Ringel M, Saji M \& Kohn L 2005 Thyrocytes express a functional toll-like receptor 3 (TLR3): overexpression can be induced by viral infection, reversed by phenylmethimazole, and is associated with Hashimoto's autoimmune thyroiditis. Molecular Endocrinology 19 1231-1250. (doi:10.1210/me.2004-0100) 
Heinrich PC, Behrmann I, Muller-Newen G, Schaper F \& Graeve L 1998 Interleukin-6-type cytokine signalling through the gp130/Jak/STAT pathway. Biochemical Journal 334 297-314.

Heinrich PC, Behrmann I, Haan S, Hermanns HM, Muller-Newen G \& Schaper F 2003 Principles of interleukin (IL)-6-type cytokine signalling and its regulation. Biochemical Journal 374 1-20. (doi:10.1042/BJ20030407)

Hirosumi J, Tuncman G, Chang L, Gorgun CZ, Uysal KT, Maeda K, Karin M \& Hotamisligil GS 2002 A central role for JNK in obesity and insulin resistance. Nature 420 333-336. (doi:10.1038/nature01137)

Hotamisligil GS 2005 Role of endoplasmic reticulum stress and c-Jun $\mathrm{NH}_{2}$-terminal kinase pathways in inflammation and origin of obesity and diabetes. Diabetes 54 (Supplement 2) S73-S78. (doi:10.2337/diabetes. 54.suppl_2.S73)

Hotamisligil GS, Peraldi P, Budavari A, Ellis R, White MF \& Spiegelman BM 1996 IRS-1-mediated inhibition of insulin receptor tyrosine kinase activity in TNF-alpha- and obesity-induced insulin resistance. Science 271 665-668. (doi:10.1126/science.271.5249.665)

Jove M, Planavila A, Laguna JC \& Vazquez-Carrera M 2005 Palmitateinduced interleukin 6 production is mediated by protein kinase $\mathrm{C}$ and nuclear-factor kappaB activation and leads to glucose transporter 4 down-regulation in skeletal muscle cells. Endocrinology 146 3087-3095. (doi:10.1210/en.2004-1560)

Kahn BB \& Flier JS 2000 Obesity and insulin resistance. Journal of Clinical Investigation 106 473-481. (doi:10.1172/JCI10842)

Khamzina L, Veilleux A, Bergeron S \& Marette A 2005 Increased activation of the mammalian target of rapamycin pathway in liver and skeletal muscle of obese rats: possible involvement in obesity-linked insulin resistance. Endocrinology 146 1473-1481. (doi:10.1210/en.2004-0921)

Kohn AD, Summers SA, Birnbaum MJ \& Roth RA 1996 Expression of a constitutively active Akt Ser/Thr kinase in 3T3-L1 adipocytes stimulates glucose uptake and glucose transporter 4 translocation. Journal of Biological Chemistry 271 31372-31378. (doi:10.1074/jbc.271.49.31372)

Lau DC, Dhillon B, Yan H, Szmitko PE \& Verma S 2005 Adipokines: molecular links between obesity and atheroslcerosis. American Journal of Physiology. Heart and Circulatory Physiology 288 H2031-H2041. (doi:10.1152/ajpheart.01058.2004)

Lin Y, Lee H, Berg AH, Lisanti MP, Shapiro L \& Scherer PE 2000 The lipopolysaccharide-activated toll-like receptor (TLR)-4 induces synthesis of the closely related receptor TLR-2 in adipocytes. Journal of Biological Chemistry 275 24255-24263. (doi:10.1074/jbc.M002137200)

Lin Y, Berg AH, Iyengar P, Lam TK, Giacca A, Combs TP, Rajala MW, Du X, Rollman B, Li W et al. 2005 The hyperglycemia-induced inflammatory response in adipocytes: the role of reactive oxygen species. Journal of Biological Chemistry 280 4617-4626. (doi:10.1074/jbc.M411863200)

McCall KD, Harii N, Lewis CJ, Malgor R, Kim WB, Saji M, Kohn AD, Moon RT \& Kohn LD 2007 High basal levels of functional toll-like receptor 3 (TLR3) and non-cannonical Wnt5a are expressed in papillary thyroid cancer (PTC) and are coordinately decreased by phenylmethimazole together with cell proliferation and migration. Endocrinology 148 4226-4237. (doi:10.1210/en.2007-0459)

Morino K, Petersen KF, Dufour S, Befroy D, Frattini J, Shatzkes N, Neschen S, White MF, Bilz S, Sono S et al. 2005 Reduced mitochondrial density and increased IRS-1 serine phosphorylation in muscle of insulin-resistant offspring of type 2 diabetic parents. Journal of Clinical Investigation 115 3587-3593. (doi:10.1172/JCI25151)

Nakamura S, Takamura T, Matsuzawa-Nagata N, Takayama H, Misu H, Noda H, Nabemoto S, Kurita S, Ota T, Ando H et al. 2009 Palmitate induces insulin resistance in H4IIEC3 hepatocytes through reactive oxygen species produced by mitochondria. Journal of Biological Chemistry 284 14809-14818. (doi:10.1074/jbc.M901488200)

Paz K, Hemi R, LeRoith D, Karasik A, Elhanany E, Kanety H \& Zick Y 1997 A molecular basis for insulin resistance. Elevated serine/threonine phosphorylation of IRS-1 and IRS-2 inhibits their binding to the juxtamembrane region of the insulin receptor and impairs their ability to undergo insulin-induced tyrosine phosphorylation. Journal of Biological Chemistry 272 29911-29918. (doi:10.1074/jbc.272.47.29911)
Perreault M \& Marette A 2001 Targeted disruption of inducible nitric oxide synthase protects against obesity-linked insulin resistance in muscle. Nature Medicine 7 1138-1143. (doi:10.1038/nm1001-1138)

Ragheb R, Shanab GM, Medhat AM, Seoudi DM, Adeli K \& Fantus IG 2009 Free fatty acid-induced muscle insulin resistance and glucose uptake dysfunction: evidence for PKC activation and oxidative stress-activated signaling pathways. Biochemical and Biophysical Research Communications 389 211-216. (doi:10.1016/j.bbrc.2009.08.106)

Schwartz AL, Malgor R, Dickerson E, Weeraratna AT, Slominski A, Wortsman J, Harii N, Kohn AD, Moon RT, Schwartz FL et al. 2009 Phenylmethimazole decreases toll-like receptor 3 and noncanonical Wnt5a expression in pancreatic cancer and melanoma together with tumor cell growth and migration. Clinical Cancer Research 15 4114-4122. (doi:10.1158/1078-0432.CCR-09-0005)

Shi H, Kokoeva MV, Inouye K, Tzameli I, Yin H \& Flier JS 2006 TLR4 links innate immunity and fatty acid-induced insulin resistance. Journal of Clinical Investigation 116 3015-3025. (doi:10.1172/JCI28898)

Smith SR \& Ravussin E 2002 Emerging paradigms for understanding fatness and diabetes risk. Current Diabetes Reports 2 223-230. (doi:10.1007/s11892002-0087-1)

Solinas G, Naugler W, Galimi F, Lee MS \& Karin M 2006 Saturated fatty acids inhibit induction of insulin gene transcription by JNK-mediated phosphorylation of insulin-receptor substrates. PNAS 103 16454-16459. (doi:10.1073/pnas.0607626103)

Steppan CM, Bailey ST, Bhat S, Brown EJ, Banerjee RR, Wright CM, Patel HR, Ahima RS \& Lazar MA 2001 The hormone resistin links obesity to diabetes. Nature 409 307-312. (doi:10.1038/35053000)

Suzuki K, Mori A, Ishii KJ, Saito J, Singer DS, Klinman DM, Krause PR \& Kohn LD 1999 Activation of target-tissue immune-recognition molecules by double-stranded polynucleotides. PNAS 96 2285-2290. (doi:10.1073/ pnas.96.5.2285)

Ueki K, Kondo T \& Kahn CR 2004 Suppressor of cytokine signaling 1 (SOCS-1) and SOCS-3 cause insulin resistance through inhibition of tyrosine phosphorylation of insulin receptor substrate proteins by discrete mechanisms. Molecular and Cellular Biology 24 5434-5446. (doi:10.1128/ MCB.24.12.5434-5446.2004)

Um SH, Frigerio F, Watanabe M, Picard F, Joaquin M, Sticker M, Fumagalli S, Allegrini PR, Kozma SC, Auwerx J et al. 2004 Absence of S6K1 protects against age- and diet-induced obesity while enhancing insulin sensitivity. Nature 431 200-205. (doi:10.1038/nature02866)

Vanhaesebroeck B \& Alessi DR 2000 The PI3K-PDK1 connection: more than just a road to PKB. Biochemical Journal 346 561-576. (doi:10.1042/ 0264-6021:3460561)

Weisberg SP, McCann D, Desai M, Rosenbaum M, Leibel RL \& Ferrante AW Jr 2003 Obesity is associated with macrophage accumulation in adipose tissue. Journal of Clinical Investigation 112 1796-1808. (doi:10.1172/JCI19246)

Wellen KE \& Hotamisligil GS 2003 Obesity-induced inflammatory changes in adipose tissue. Journal of Clinical Investigation 112 1785-1788. (doi:10. 1172/JCI20514)

Xu H, Barnes GT, Yang Q, Tan G, Yang D, Chou CJ, Sole J, Nichols A, Ross JS, Tartaglia LA et al. 2003 Chronic inflammation in fat plays a crucial role in the development of obesity-related insulin resistance. Journal of Clinical Investigation 112 1821-1830. (doi:10.1172/JCI19451)

Yu C, Chen Y, Cline GW, Zhang D, Zong H, Wang Y, Bergeron R, Kim JK, Cushman SW, Cooney GJ et al. 2002 Mechanism by which fatty acids inhibit insulin activation of insulin receptor substrate-1 (IRS-1)-associated phosphatidylinositol 3-kinase activity in muscle. Journal of Biological Chemistry 277 50230-50236. (doi:10.1074/jbc.M200958200)

Zick Y 2005 Ser/Thr phosphorylation of IRS proteins: a molecular basis for insulin resistance. Science's STKE : Signal Transduction Knowledge Environment 2005 pe4. (doi:10.1126/stke.2682005pe4)

Received in final form 29 July 2010

Accepted 2 September 2010

Made available online as an Accepted Preprint 2 September 2010 